\title{
Social policy in Slovenia and Montenegro: Comparing development and challenges
}

\author{
MAŠA FILIPOVIČ HRAST, UGLJEŠA JANKOVIĆ AND TATJANA RAKAR
}

\section{$S$ sciendo}

Politics in Central Europe (ISSN: 1801-3422)

Vol. 16, No. 3

DOI: $10.2478 /$ pce-2020-0031

\begin{abstract}
Slovenia and Montenegro have a common past; however, they have also experienced diverse developments in the field of social policy over the last three decades. The social policy of the two countries is based on a Yugoslav welfare model, and yet the positions of the two countries were quite rather different even as part of Federal Yugoslavia, with Slovenia being one of the most developed territories within the federation, while Montenegro was one of the least developed. In this article, we will describe the position and main challenges of the transition of the two countries from 1990 in relation to the developments and changes in the core fields of social policy, such as the labour market and social assistance, family policy and old age policy. The emphasis will be on linking the diverse starting points, the process of transition and the direction of developments, within the framework of path dependent changes in the two welfare systems, as well as a discussion of the relevant structural pressures, such as the economic and social situation of the two countries and ways of coping with these pressures that were employed. In the conclusion, the changes within the individual fields of social policy will also be discussed in relation to the prevalent discourses of the neoliberal transformation of modern welfare states, along with the development of social investment perspectives within social policy as a whole.
\end{abstract}

Keywords: social policy, welfare system, transition, Slovenia, Montenegro

\section{Introduction}

Slovenia and Montenegro have a common social policy background based on a specific Yugoslav welfare model, which offered a rather generous welfare system. Although social insurance for some categories of workers for certain 
social risks existed in the Kingdom of Yugoslavia, the system remained rather underdeveloped and was inconsistently implemented (Stambolieva 2016: 24). In Federal Yugoslavia, a mixed Bismarckian-Beveridgean system was constructed, encompassing both social insurance and social protection. The social insurance system included several branches, for example health insurance, pension and disability insurance and temporary unemployment insurance. The core of the social protection system was targeted toward the neediest, while in a broader sense, the beneficiaries were all workers, their families and whole communities, who benefited from different services provided mostly by companies and municipalities (Stambolieva 2016: 24). However, despite the common welfare system, intrinsic differences, stemming from differences in economic circumstances and the allocation of resources, created significant discrepancies between different regions (at that time, the constituent republics and provinces), which resulted in significant variations in the scope and quality of the social programmes. In the 1970s, the greater autonomy of the federal units reinforced these diverging trends, which significantly intensified in the transition period after the collapse of Yugoslavia (see Stambolieva, 2016). The transition period in the former Yugoslavia had four phases: a) macro-economic stabilisation; b) liberalisation; c) privatisation; and d) re-structuring (Lazić 2000). Many were hoping that political pluralism and the market economy were tested paths that the citizens of Eastern and Central Europe would rush down on their way to a society of abundance and freedom (Lazić 2011). However, the countries followed divergent paths in relation to both the transition and the democratisation process, with both being smoother and faster in Slovenia, and slower in Montenegro (see Komar and Novak 2020).

Slovenia is generally perceived as a transition success story among post-socialist countries (Stambolieva 2016). From the time it declared its independence from Yugoslavia in 1990 until the beginning of the global recession in 2008, Slovenia featured both strong economic growth and a comparatively high standard of living. It was also amongst the first of the former Eastern Bloc territories to join the European Union, the first of these newcomers to preside over the EU, holding the rotating EU presidency of the European Council in the first six months of 2008, and was among the first to join the Eurozone. During the transition period following Slovenia's independence, the left-oriented political elite opted for gradual reforms of the welfare system rather than the 'shock therapy' that was experienced by some other post-socialist countries (Kolarič et al. 2009; Ferge 2001). Based on the legacy of the well-developed state welfare system and gradual reforms, the Slovene welfare system developed as a dual model, combining elements from both the conservative-corporatist model and the social-democratic model, based on the Esping-Andersen (1990) typology. First, the characteristics of the conservative regime are the use of compulsory social insurance systems, which are the primary instrument for 
the provision of social protection for employees and their family members. On the other hand, as is found under the social-democratic regime, the strong public and state sector maintained the status of the main service provider of all types of services to which all citizens are equally entitled (Kolarič et al. 2009; Filipovič Hrast - Rakar 2017).

By contrast, in Montenegro, numerous social and economic problems that came about as a result of the process of transition have continued to the present-day, despite certain optimistic expectations. Slovenia came out of its transition process as a success story while in Montenegro the process of transition triggered a process of the retraditionalisation of the society, in which many of the positive elements of the modernisation of the previous Yugoslav period were also lost. Transition theoreticians argue that the period of transition was affected by the following: the economic structure as a limiting factor of transition, the reproduction of the state bureaucracy, the reproduction of the class structure, the reproduction of cultural patterns grounded in traditional society, the social expectations of the population, the reproduction of collectivism, the reproduction of authoritarianism, the methods used to realise of transition, and the existing international relations (Bešić 2000: 125-131). Additional circumstances that distinguish the two countries and hindered the transition in Montenegro included war in the region, the large number of refugees and migrants and the international sanctions that were imposed to the Federal Republic of Yugoslavia, of which Montenegro remained a part until 2003. In these circumstances, the final effects of transition were reflected in strong social stratification. Certain elements of modernisation that were present in the former Yugoslav society (in the spheres of health, education and housing policies, for example) were lost. The evident polarisation of Montenegrin society resulted in a division of the population into "winners" and "losers" in relation to the transition processes. Members of the newly formed economic elite have become a significant social subject in Montenegro, and have held significant sway in political decision-making. On the other hand, the "losers" in the process of transition have faced problems in terms of existential functions, and their low position on the social scale has further been marked by a rapid reduction in opportunities for adequate social participation, which has resulted in the spreading of social exclusion. The process affected almost all categories of the Montenegrin population, particularly those who were qualified and semi-qualified workers in former social enterprises, youth people and the older population. Additionally, refugees and migrants also faced the consequences of these social crises immediately upon their arrival in Montenegro.

The measures employed by policy creators in Montenegro towards the end of the 1990s were short-term in nature, and mainly aimed at "putting out fires". The social policies were not adequate in facing serious challenges, nor was there a tradition of applying the mechanisms of social policies to address 
poverty (Madžar 2000: 97). GDP dropped by a half in the period between 1990 and 2000, and the influx of refugees and migrants placed additional strain on the exhausted social funds (Ardarenko - Đurović 2004: 4). All social positions were ossified. The "winners" in the process of transition attempted to preserve or increase the wealth they had accumulated in the transitional currents. The poor struggled to escape the vicious cycle of poverty, especially due to a lack of extensive state policies with long-term effects. A wide range of social programmes became inaccessible to a vast number of people, and the implementation of significant activities that were not ad-hoc in character, and that aimed at the mitigation of these consequences began only in $2000^{1}$. Accordingly, we can argue that the implementation of comprehensive socio-political measures in Montenegro started at the beginning of the $21^{\text {st }}$ century, and mainly intended to eliminate the consequences of the policies of the last decade of the $20^{\text {th }}$ century, with a pronounced intention to contribute to the transformation of Montenegrin society, in line with the conditions of the functioning of the market.

In this article, we will describe the position and main challenges of the transition of the two countries from 1990 in relation to various developments and changes in the field of social policy, by analysing the main policy changes in the core fields of social policy such as the labour market and social assistance, family policy and old age policy. The emphasis will be on linking the diverse starting points, the process of transition and the direction of developments, within the framework of path dependent changes to the two welfare systems, as well as a discussion of a range of structural pressures - such as the economic and social situation of the two countries and the preferred means of coping with these pressures. We argue that more differences than similarities can be found between the two welfare systems and their developments, which can be traced back to the beginning of the transition, the various paths that the countries chose in tackling their social issues, as well as the different pressures that they have faced over the last three decades.

\section{The social and economic context}

The social and economic context is one of the relevant factors for understanding the success of the process of democratisation (see Komar and Novak 2020), and specific social and economic conditions also determine particular social policy responses. According to Lakićević (1997), "the social crisis of the former Yugoslav society was caused by the lack of flexibility of the economic, technological and political systems to adapt and change, which resulted in the

1 During 1990/2000 in Montenegro, there were a number of short time social actions by the state, which were focused on particular groups of people (refugees, pensioners, unemployment people, and so on). In general, these type of state actions included short time material support and some benefits related to living conditions. 
deterioration of the overall social situation, particularly in comparison with developed countries at the time" (Milosavljević 2004). This legacy is especially evident in Montenegro.

The beginning of the essential economic transition in Montenegro started in the final years of the $20^{\text {th }}$ century, with the process of the transformation of ownership, privatisation and the introduction of the Deutsche Mark as the official currency, which made numerous problems more visible (Katnić 2017). The economic transition that implied moving from a centrally planned economy to market structures contributed to the creation of thousands of private companies, and to re-orientation of the economy from industry to service provision. The transformation of the economy resulted in the reduced relevance of agriculture and industry, and increased the importance of service provision and trade (Katnić 2017: 13). Montenegro entered the $21^{\text {st }}$ century with an inherited socio-economic legacy derived from the previous economic system, and the creators of the social and economic policies were faced with accumulated reform challenges.

In social and economic terms, Slovenia was the frontrunner among the ex-Yugoslav countries, which was also evident in its relatively quick economic recovery after the crisis in the 1990s, when there were high unemployment rates. The GDP growth in the 2000s was relatively fast and higher than in Montenegro until 2005, when Montenegro experienced high growth (see Table 1). Both countries experienced a decrease in GDP growth in 2008, with Slovenia experiencing lower growth than Montenegro until 2014.

\section{Table 1: GDP growth (annual \%)}

\begin{tabular}{|c|c|c|c|c|c|c|c|c|c|c|c|c|c|c|c|c|}
\hline & 2000 & 2001 & 2002 & 2003 & 2004 & 2005 & 2006 & 2007 & 2008 & 2009 & 2010 & 2011 & 2012 & 2013 & 2014 & 2015 \\
\hline Montenegro & 3.1 & 1.1 & 1.9 & 2.5 & 4.4 & 4.2 & 8.6 & 6.8 & 7.2 & -5.8 & 2.7 & 3.2 & -2.7 & 3.5 & 1.8 & 3.4 \\
\hline Slovenia & 4.2 & 2.9 & 3.8 & 2.8 & 4.4 & 4.0 & 5.7 & 6.9 & 3.3 & -7.8 & 1.2 & 0.6 & -2.7 & -1.1 & 3.0 & 2.3 \\
\hline
\end{tabular}

Source: World Bank 2019.

The relatively good social position in Slovenia is illustrated by its low poverty rates (see Table 3) as well as its low levels of inequality. In Slovenia, the Gini coefficient has remained stable at relatively low levels below 25 per cent, while in Montenegro it is higher, i.e. above 30 (see Table 2). This reflects the already mentioned greater stratification of Montenegrin society after the transition.

While the at-risk-of poverty rates are relatively low in Slovenia, they rose as a consequence of the economic crisis starting in 2008, most evidently after 2010, reaching $14.3 \%$ in 2015 . Poverty rates are low among children, usually lower than that found in the general Slovene population, and dropped significantly 
Table 2: Gini coefficient

\begin{tabular}{|l|c|c|c|c|c|}
\hline & 1995 & 2000 & 2005 & 2010 & 2015 \\
\hline GINI COEFFICIENT & & & & & \\
\hline EUROPEAN UNION (15 COUNTRIES) & 31 & 29 & $:$ & $:$ & $:$ \\
\hline EUROPEAN UNION ** & $:$ & $:$ & $:$ & 30.5 & 31.0 \\
\hline SLOVENIA & $:$ & 22 & 23.8 & 23.8 & 24.5 \\
\hline SLOVENIA (WB) & $:$ & $:$ & 24.6 & 24.9 & 25.4 \\
\hline MONTENEGRO (WB) & $:$ & $:$ & 30.2 & 28.9 & 31.9 \\
\hline
\end{tabular}

Note: **(, EU15-2004, EU25-2006, EU27-2013, EU28)

Source: Eurostat 2018, some data from World Bank 2019 (marked WB).

from 2015 to 2018, returning to pre-crisis levels. Older people, on the other hand, represent a more vulnerable group, with higher at-risk of poverty rates than is found in the general population; even so, this rate has been decreasing steadily since 2005. One of the most vulnerable groups in Slovenia are the unemployed, who face extremely high at-risk of poverty rates, which have not reset and dropped after the crisis, remaining as high as $45.6 \%$ in 2018 (see Table 3).

Table 3: At risk of poverty rates for Slovenia ( $60 \%$ of median equivalised income after social transfers)

\begin{tabular}{|l|c|c|c|c|c|}
\hline Slovenia & 2000 & 2005 & 2010 & 2015 & 2018 \\
\hline Total & 11 & 12.2 & 12.7 & 14.3 & 13.3 \\
\hline Under 18 & $:$ & 12.1 & 12.6 & 14.2 & 11.7 \\
\hline 65 and over & 21 & 20.3 & 20.2 & 17.2 & 18.3 \\
\hline Men & 11 & 10.6 & 11.3 & 13.0 & 12.6 \\
\hline Women & 12 & 13.7 & 14.1 & 15.6 & 14.0 \\
\hline Unemployed & 42 & 25.1 & 44.2 & 44.9 & 45.6 \\
\hline
\end{tabular}

Source: Eurostat 2019. 
Table 4: Poverty line in Montenegro

\begin{tabular}{|c|c|c|c|c|}
\hline Year & Absolute poverty line & Poverty rate (\%) & $\begin{array}{c}\text { The depth of } \\
\text { poverty (\%) }\end{array}$ & $\begin{array}{c}\text { The severity of } \\
\text { poverty (\%) }\end{array}$ \\
\hline 2006 & 144.68 & 11.3 & 1.9 & 0.6 \\
\hline 2007 & 150.76 & 8.0 & 1.4 & 0.4 \\
\hline 2008 & 163.57 & 4.9 & 0.9 & 0.3 \\
\hline 2009 & 169.13 & 6.8 & 1.4 & 0.5 \\
\hline 2010 & 169.98 & 6.6 & 1.1 & 0.3 \\
\hline 2011 & 172.25 & 9.3 & 2.0 & 0.7 \\
\hline 2012 & 182.43 & 11.3 & 2.8 & 1.4 \\
\hline 2013 & 186.45 & 8.6 & 2.4 & 1.1 \\
\hline
\end{tabular}

Source: MONSTAT 2019, Department of Labour Market Statistics, Living conditions, Social services and Household consumption.

Table 5: Dispersion around the threshold of poverty risk in Montenegro

\begin{tabular}{|c|c|c|c|c|c|}
\hline & 2013 & 2014 & 2015 & 2016 & $2017^{(p)}$ \\
\hline \multicolumn{6}{|c|}{ The poverty risk when the threshold is } \\
\hline $40 \%$ (40\% median) & 16.2 & 11.9 & 13.5 & 12.9 & 11.9 \\
\hline $50 \%$ (50\% median) & 21.9 & 17.4 & 19.9 & 18.7 & 17.2 \\
\hline 70\% (70\% median) & 33.4 & 32.5 & 31.9 & 31.2 & 30.4 \\
\hline
\end{tabular}

Source: MONSTAT 2019.

The expenditure associated with household consumption that determines the poverty line in Montenegro increased between 2006 and 2013 - from $€ 144.68$ in 2006 , to $€ 186.45$ in 2013. Simultaneously, the number of poverty-stricken people (the poverty rate) decreased by almost a half between $2006(11.3 \%)$ and 2010 (6.6\%) (see Table 4). However, the trend in the deteriorating social situation continued from 2010 , and the rate of poverty was at $8.6 \%$ in 2013 . The depth of poverty shows how much income should be transferred to people affected by poverty in order for household income to increase and move beyond the poverty line. Accordingly, the number of people who should be provided 
with these transfers increased from 1.9\% in 2006 to $2.4 \%$ in 2013 (see Table 4). Additionally, the number of people who are the farthest away from the poverty line in relation to those who are the closest to the line (that is, the severity of the poverty experienced) reduced in the period between 2006 (from $0.6 \%$ ) and 2010 (to 1.1\%). Poverty is more prevalent in larger households, as well as among older people (65 or above), and among the unemployed or retired. Households, in which an adult female or a person over the age of 65 is the sole or main income provider, are at a particular risk of poverty. Essentially, it is age, education, status and the type of employment that drive the risk of poverty. According to the data, (see Table 5) we can note a statistically significant difference in the coverage of the risk of poverty depending on whether the median is at $40 \%$ or $50 \%$ of the average income of household members. Compared to the situation in 2013, the risk of poverty has decreased but Montenegro is still far from meeting those standards that guarantee the stable position of a larger number of households and a minimal risk of poverty.

Social protection expenditure has remained stable in Slovenia, being at the same level, $23.7 \%$ of current GDP, both in 2000 and in 2015 (see Table 6). The largest share of social protection is represented by social protection benefits. By function, the largest share is intended for old age and widows/widowers, which represent almost half of the expenditure, followed by expenditure on sickness benefit and healthcare, which forms approximately 39\% of total expenditure. A significant share of the remaining budget is used for families and children, which has decreased slightly from $8.97 \%$ of the budget in 2000 to $7.5 \%$ in 2015 . On the other hand, the share taken by unemployment benefits has been decreasing steadily, from $4.15 \%$ in 2000 to $2.69 \%$ in 2015 , while the expenditure on social exclusion has increased from $1.6 \%$ in 2000 to $3.11 \%$ in 2015.

The share of the overall budget used for social and child protection in Montenegro is somewhat lower, being $17.4 \%$ of GDP in 2017. The distribution follows a similar pattern to that of Slovenia, where the largest share of expenditure is intended for old age protection (39.5\% in 2017), followed by expenditure on sickness benefits and healthcare $(27.7 \%)$. The share used for employment benefits is similar to that in Slovenia, at. approximately $2 \%$, as well as the shares given to families and children and to social exclusion $(7.7 \%$ and $2.7 \%$ respectively) (see Table 7 ).

In sum, the analysis clearly shows that in the examined period of transition, Slovenia had more favourable social and economic circumstances in comparison to Montenegro, which is clearly reflected in the differences within the countries changing welfare systems. These are characterised by diverse social policy developments, as is shown in the next section. 
Table 6: Social Protection Benefits by Function, 2000-2015 (\% of total expenditure) and social protection expenditure as a share of GDP in Slovenia

\begin{tabular}{|l|c|c|c|c|}
\hline & 2000 & 2005 & 2010 & 2015 \\
\hline Slovenia & & & & \\
\hline Social protection expenditure as a \% of GDP & 23.7 & 22.6 & 24.4 & 23.7 \\
\hline Total expenditure & 100 & 100 & 100 & 100 \\
\hline Social protection benefits & 97.42 & 97.85 & 97.9 & 98.3 \\
\hline Family/children & 8.97 & 8.41 & 8.69 & 7.5 \\
\hline Unemployment & 4.15 & 3.2 & 2.69 & 2.69 \\
\hline Housing & 0 & 0.06 & 0.04 & 0.1 \\
\hline Social exclusion n.e.c. & 1.6 & 2.78 & 2.34 & 3.11 \\
\hline Sickness / healthcare and disability & 38.65 & 40 & 38.65 & 37.43 \\
\hline Old age and survivors & 44.05 & 43.4 & 45.49 & 47.47 \\
\hline
\end{tabular}

Source: Eurostat 2018.

Table 7: Social Protection Benefits in Montenegro

\begin{tabular}{|c|c|c|c|c|}
\hline $\begin{array}{c}\text { Social and Child Protection in } \\
\text { Montenegro }\end{array}$ & $\begin{array}{c}2016 \text { (\% of } \\
\text { GDP) }\end{array}$ & $\begin{array}{c}2016 \\
\text { (\% of total } \\
\text { costs) }\end{array}$ & $\begin{array}{c}\text { 2017(\% of } \\
\text { GDP) }\end{array}$ & $\begin{array}{c}2017 \\
\text { (\% of total } \\
\text { costs) }\end{array}$ \\
\hline $\begin{array}{l}\text { Total costs for social and child } \\
\text { protection }\end{array}$ & 18.7 & & 17.4 & 17.4 \\
\hline $\begin{array}{l}\text { Total costs for social benefits by } \\
\text { functions }\end{array}$ & 18.2 & 100 & 16.8 & 100.0 \\
\hline Sickness / health care & 4.8 & 26.3 & 4.7 & 27.7 \\
\hline Disability & 1.5 & 8.3 & 1.5 & 8.7 \\
\hline Old age & 7.0 & 38.6 & 6.7 & 39.5 \\
\hline Successors & 2.2 & 12.0 & 2.1 & 12.3 \\
\hline Family / children & 1.9 & 10.4 & 1.3 & 7.7 \\
\hline Employment & 0.4 & 2.3 & 0.3 & 2.0 \\
\hline $\begin{array}{c}\text { Social exclusion non/registration in } \\
\text { other categories }\end{array}$ & 0.4 & 2.2 & 0.4 & 2.1 \\
\hline
\end{tabular}

Source: MONSTAT 2016, 2017. 


\section{A comparative overview of social policy developments in Slovenia and Montenegro}

In this section, we offer a short overview of the policy changes in separate policy areas after the transition in each country. The main distinction between countries is the gradual approach to policy changes in Slovenia, while in Montenegro, the measures employed by policy creators at the end of the 1990 s were short-term, and mainly aimed at "putting out fires". The social policies were not adequate in facing serious challenges, nor was there a tradition of applying the mechanisms of social policies to address poverty (Madžar 2000: 97). The positive economic situation in Slovenia after the transition also allowed a degree of expansion of the existing social policy measures in that country, while the worse economic position in Montenegro, where GDP decreased by a half in the period between 1990 and 2000, and the influx of refugees and migrants (Croatia, Bosnia and Herzegovina and especially Kosovo in 1999) placed additional strains on its already exhausted social funds (Ardarenko - Đurović 2004: 4).

However, the beginning of the $21^{\text {st }}$ century brought important changes; in Slovenia the effect of the economic crisis of 2008 was strongly felt and lead to a more in depth restructuring of the system with the goal of cutting costs and increasing its long-term sustainability. On the other hand, in Montenegro, the implementation of these types of comprehensive socio-political measures only started at the beginning of the $21^{\text {st }}$ century, and mainly aimed at eliminating the consequences of the decisions and pressures of the 1990s, with a pronounced intention to contribute to the transformation of Montenegrin society. During the first decade of the $21^{\text {st }}$ century, various processes of social structuring and social stratification in Montenegro were the result of the lack of a link between economic, cultural and social capital. The ways in which individuals, families, households and local communities reacted to the frequent shocks they experienced in terms of income and earnings have not been examined systemically before.

\section{The labour market}

The labour market in Slovenia experienced two major crises resulting in high unemployment rates: one in the early 1990s associated with the transition from the Yugoslav economic system to a market economy, and the in 2009 related to the global economic crisis (see Ignjatović - Filipovič Hrast 2018). The 1990s were notable for the ongoing, relatively generous insurance based unemployment system (Stropnik - Stanovnik 2002). However, there was a continual gradual retrenchment of the system, where the maximum payments were decreased and period for receiving the benefit shortened (Ignjatović et al. 2002; Ignjatović Filipovič Hrast 2018). Furthermore, in 1998 the basis for determining the level of compensation was changed from three to twelve months' average salary, while 
there was also a lengthening of the insurance record (Stropnik - Stanovnik 2002). These very gradual retrenchment trends continued in the second decade after independence, i.e. from 2000 onward. Another important retrenchment measure in this period was the abolition of non-contributory based unemployment assistance in 2006. Along with these developments, the introduction of social investment measures was also evident in the form of active labour market policies. These policies were particularly evident in the introduction of training, career orientation measures and educational support measures for the unemployed; however, this was accompanied by increased conditionality in access to unemployment rights, which were linked to active engagement in searching for a job (Ignjatović et al. 2002; Kopač 2005; Filipovič Hrast - Rakar 2019).

With the onset of the global economic crisis in 2008 and the effects of that recession, which had a significant impact on the Slovene economy and caused high unemployment rates, there were several policy changes adopted in the field of labour market, designed to address these new challenges. These responses varied from relatively generous temporary measures such as a partial subsidy of full-time work for part-time workers and the introduction of 'temporary waiting-to-work' under special conditions, to more permanent expansionary measures brought about by legislation changes in the period from 2010 to 2013. The latter included increasing protection for more vulnerable workers, raising the minimum wage, softening the eligibility criteria for those with a more irregular employment record, increasing the level of unemployment benefit and raising contributions for fixed term contracts to stimulate permanent contracts, as well as introducing severance pay for those on fixed term contracts (see also Ignjatović - Filipovič Hrast 2018).

Despite this relatively generous and expansionary approach, the generally implemented austerity measures limited and reduced some of the more generous changes to the labour market, e.g. by reducing the benefit levels (see Ignjatović - Filipovič Hrast 2018). Furthermore, one of the important labour market trends has been its segmentation and the increasing share of workers with flexible contracts (e.g. fixed term, student work) which are used by employers to reduce labour costs and increase flexibility (Ignjatović 2002; Kanjuo Mrčela - Ignjatović 2015; Ignjatović - Filipovič Hrast 2018). These problems remained inadequately addressed by the described policy changes. Active labour market policies were implemented; however, their strengthening and further development was limited due to a lack of resources. Specifically, the amount of resources for active labour market policies is lower than the EU average and also decreased after 2013 (Eurostat 2019; see Ignjatović - Filipovič Hrast 2018; Trbanc et al. 2017).

The issue of unemployment in Montenegro is the leading social and individual problem. Montenegro entered the process of transition, which was marked by an overall social crisis. The former Yugoslav economic system was not able 
to accumulate and invest even the absolute minimum of its economic means, or to repay its accumulated debt, and the political system lacked the capacity to generate any positive economic or political changes (Milosavljević 2004: 43). According to the data on registered unemployed people in Montenegro, the number of unemployed reached the highest value in 2000, when the average number of registered unemployed was 83,583 . Such a situation was caused by the war in Yugoslavia, and a large number of migrants and refugees finding refuge in Montenegro at the end of the 1990s. After that period, unemployment rates were on a constant decline, and the lowest number of unemployed was recorded in 2008, when there were 42.200 unemployed registered in the country. As a consequence of the global economic crisis, unemployment rates increased in 2009 and 2010. Additionally, unemployment rates of the working age population were particularly high from 2012 to the first quarter of 2015, when it ranged between $20.7 \%$ (in the first quarter of 2012) and $18.2 \%$ (in the first quarter of 2015). The rate of unemployment has decreased in recent years, but it remains relatively high. Last year (2018), Montenegro had a 15.2\% rate of unemployment, which is the lowest rate recorded in the past ten years.

\section{Table 8: Unemployment in Montenegro (in percentages of working age population)}

\begin{tabular}{|c|c|c|c|}
\hline Year & Total & Men & Women \\
\hline 2013 & 19.5 & 20.0 & 18.8 \\
\hline 2014 & 18.0 & 17.8 & 18.2 \\
\hline 2015 & 17.6 & 17.7 & 17.3 \\
\hline 2016 & 17.7 & 18.2 & 17.1 \\
\hline 2017 & 16.1 & 15.4 & 17.0 \\
\hline 2018 & 15.2 & 15.2 & 15.1 \\
\hline
\end{tabular}

Source: MONSTAT 2018.

In the last six years in Montenegro, according to official data, there has been a reduction in unemployment (see Table 8). Moreover, there is no significant difference in the rate of unemployment between men and women. In Montenegro, as in Slovenia, there is an increasing emphasis on the concept of activation. The creators of policies have opted for strategic approaches to solving the problem of unemployment. In the past few years, various strategies and action plans have been devised to propose new measures and instruments for reducing unemployment. Youth is a primary point of focus in these strategies (as a particularly at risk category for unemployment), as well as people with disabilities (who fall in the category of hard-to-employ, and the category of us- 
ers of financial help). The policy of employing the older population has not yet been fully affirmed in Montenegro.

During 2018, financial assistance for unemployment in Montenegro was provided to 9,366 unemployed people. Unemployment finance benefit amounts to $40 \%$ of the minimum wage in Montenegro. In addition, within the amount of financial assistance we should also calculate and pay contributions for health and pension - disability insurance. Until 2019, under the Labour Law, financial assistance for unemployed people in Montenegro amounted to 77 euros a month. The new Labour Law includes changes to amount of financial compensation offered (as of April, 2019), and the financial assistance increased from 77 to 108 euros a month, indicating an expansionary response. The reason for the increase is the accompanying increase of the minimum wage in Montenegro from $193 €$ to $222 €$ per month. The minimum period for which financial assistance is paid is three months (for unemployment people with an insurance period of one to five years), and the maximum is 12 months (for those who are insured with more than 25 years of insurance period coverage).

\section{Family policy}

Family policies in Slovenia have played a central role in supporting high labour market participation among women, which has been a tradition in Slovenia for more than half a century. This was sustained by the development of a widespread network of childcare services, and the introduction of insurance-based social security schemes in the case of maternity (i.e. maternity/parental leave) and other family-related benefits (e.g. child benefits). Additionally, an individual tax system was established. After its independence, Slovenia preserved its well-developed family policy measures from the Yugoslav period. Hence, Slovenia has a relatively well-developed family policy, particular in terms of parental leave and preschool child care, enabling the reconciliation of work and family life, providing equal opportunities for men and women and a horizontal redistribution of income in favour of families with children and the disadvantaged (Stropnik 2014). However, following the 2008 economic crisis, various austerity measures and the introduction of the new social legislation with policy modifications, retrenchment has been particularly evident, with the introduction of strict(er) means testing and targeting. Universal benefits, such as the large-family allowance and the childbirth grant, have become means-tested. Furthermore, although the government's austerity measures regarding family policy have mainly affected cash benefits, these policies have also been connected to reductions in social investments. It was only services such as childcare for which no austerity measures were introduced. Likewise, leave policies were affected to some extent, where retrenchment was evident as wage compensation for parental and paternity leaves were lowered and an upper ceiling for the maternity- 
-leave benefit was introduced (Filipovič Hrast - Rakar 2019). These changes to child benefits and the introductions of austerity measures have lowered the number of child-benefit recipients and reduced government expenses. This is in line with increased selectivity as one of the main dimensions of post-crisis policy in European welfare states (Taylor Gooby et al. 2017). It should be noted that this is the first time since Slovenian independence that family policy has been affected by austerity measures. After 2014, but most especially after 2018 , certain expansionary measures were again introduced ${ }^{2}$.

Family policy in Montenegro is not independent public policy. Generally, measurement's and instruments of family policy are incorporate in social protection activities ${ }^{3}$. The Law of Social and Child Protection (2013) is based on the principles of decentralization, de-institutionalization and the development of community services. Child protection is an activity of public interest and the public interest provided by the state and local municipalities, under conditions prescribed by The Law on Social and Child Protection. The Act stipulates that municipalities will participate in the financing of measures and programmes for the development of child protection, as well as providing material benefits. In addition, child protection in Montenegro is focused on particular child populations and their families according to The Law of Social and Child Protection. This law introduced novelties related to supervisory jobs in social work, inspection, and the model of functioning of the public procurement of social services and child protection. In the course of reform, progress has been made in the development and application of information technology and after many years of professional effort the Social Welfare Information System - Social Card (IISSS) was introduced (IDEAS 2019). Overall, only those eligible for social and child protection in Montenegro can use the various forms of tangible and intangible support based on The Law of Social and Child Protection (2013). Several financial measures are in place, such as: material support for new-born children,

2 Minor changes were adopted in 2014, changing some aspects of parental and paternity leaves, child benefits for single parents and the rights of social parents and introduced more gender-equal leave policies. In the social investment field, this expansion was evident in the prolongation of paid paternity leave; however, this was introduced based on a delayed and gradual implementation dependent on GDP growth. The new law also responded to the increases in poverty among single-parent households by increasing benefits for single parents. However, these changes affect only a very small percentage of single-parent households, because of the narrow definition of a 'single-parent family', thus creating an implementation gap (Rakar 2015). In 2018, the government abolished some of the austerity measures with regard to child benefit, the child birth grant, the large family allowance and finally implemented the policy of 30 days of paid paternity leave.

3 The most important acts are: The Law on Social and Child Protection, "Official Gazette of Montenegro", 27/2013, 1/2015, 42/2015, 47/2015, 56/2016, 66/2016, 1/2017, 31/2017 - decision of the CC, 42/2017 and 50/2017 (2013), the Law on Protection from Family Violence "Official Gazette of Montenegro", 46/2010 (2010). The Family Law, "Official Gazette of Montenegro", 1/2007, 53/2016 (2007), the Law on the Treatment of Juveniles in Criminal Proceedings, "Official Gazette of Montenegro", 64/2011 (2011), the Law on the Prohibition of Discrimination of Persons with Disabilities, "Official Gazette of Montenegro", 39/2011 (2011), and the Strategy for the Prevention of Violence and Protection of Children from Violence (2017-2021). 
material support for children, food assistance in pre-school facilities, care support and benefits, the refund of earnings during pregnancy leave and maternity leave, including for people engaged in entrepreneurial activities, assistance for parents of new-born children, the refund of earnings to the employer for employees who engage in working half-time, and the earnings of people who engage in entrepreneurial activity half-time.

The system is targeted mostly at those most in need, and therefore lacks more universal approach that can be found in Slovenia. The present practice of support for families and children who are not eligible for social services and child protection measures was reduced to sporadic implementation. For example, in Podgorica (the capital of Montenegro) a flat tax (municipal tax) is paid according to the number of family members. The government of Montenegro has provided financial support to families with three or more new-born children from the budget reserve over recent years. Furthermore, local municipalities in Montenegro have had local projects for the distribution of school books and materials to children for free. Generally, though, we cannot speak about a proactive and progressive family policy based on universal principles.

\section{Old age policy}

Population aging is a phenomenon that typifies almost all European societies, and is an issue that affects Montenegro as well as Slovenia. Slovenia is faced by the intensive ageing of its population and the old age dependency ratio is projected to rise to $57.6 \%$ in 2060, from $24.4 \%$ in 2012 (Eurostat 2018). In the policy field, the most important tool to address this, but also the most relevant challenge, is the pension systems. Slovenia has a pay-as-you-go system introduced after World War II (Stanovnik 2002). This system has gradually changed since the 1990s, with smaller and incremental changes such as the tightening of the eligibility conditions, limiting the ratio between pensions and wages and increasing the retirement age. In 1999, a three-pillar system was introduced; however, the main plank of this system is the first pillar based on compulsory insurance. Additional reforms addressed the sustainability of the system further and tightened eligibility, such as increasing the retirement age (to 63 for men and 61 for women), as well as increasing the period for which the highest average earning is calculated (Stanovnik 2002; Filipovič Hrast - Rakar 2019). While the first pillar remained the most important, the inclusion in the scope of the second pillar also increased, but this was not enough to address the reduction of the rights inherent in the changes made to the first pillar (see Verbič 2009). Although the changes remained gradual, they were part of more general retrenchment measures, as the retirement age was increased again and also equalised for men and women, while the non-contributory old age state pension was abolished (see also Filipovič Hrast - Rakar 2019). 
Similarly, in Montenegro, the demographic trends in the past 50 years indicate that the population is aging. One positive trend in the demographic structure is higher life expectancy, but the declines in the percentage of residents younger than 15 , and the population aged 15-24, are particularly concerning. The share of youth in the total population of Montenegro decreased by $6 \%$ between the 1950 s nd the first decade of the $21^{\text {st }}$ century. Furthermore, according to UN population projections, by 2050, the share of population aged 15-24 will be half what is was in 1950 (Katnić 2017: 40). We can identify a number of negative effects that are a result of the demographic trends of an aging population in Montenegro. The instability of the pension system in Montenegro is caused by the unstable relationship between the active and passive population. Persistent problems in the health system in Montenegro are demonstrated by dysfunction in primary health care, the lack of flexibility in the system, long waiting lists, and so on. The reaction of policy makers to these social problems were mainly focused on strategic approaches to the reform of both pensions and the health system. However, a lot of the planned measures and instruments did not produce the expected results. The reforms made to the pension system in 2004 and 2010 were aimed at ensuring the long-term sustainability of the pension system in Montenegro; however, the implemented mechanisms encouraging early retirement, lowing the average age of people who retire, while reducing the number of years of contribution increased the overall number of pensioners vis-a-vis the number of employees who pay contributions. This, together with the demographic trends, has in fact endangered the financial sustainability of pension fund. The average pension in Montenegro in 2018 was 284 euros. The Pension Fund of Montenegro is also not completely financially independent, and pensions are paid regularly in part thanks to funds provided by the government and allocated to the Pension Fund (PIO). For complete financial independence, the optimal ratio for the Pension Fund of Montenegro is one pensioner for every three employees. The World Bank recently suggested (2018) that the government of Montenegro needs to proceed with changes to the PIO. Representatives of the World Bank have asked Montenegro to establish a special fund for financing privileged pensions, revise the list of occupations covered by this category, increase employment among older workers and work to limit early retirement (World Bank, 2019). This indicates an incomplete reform process in Montenegro, which is, however also reflected in Slovenia, where despite several attempts at reform, the overall reform process is not yet complete and further changes are needed to achieve the full sustainability of the pension system. 


\section{Social assistance}

In Slovenia, financial assistance, targeting the more vulnerable groups, is available through a form of financial social assistance, one-off financial support, a supplementary allowance, a rent subsidy, child benefits and a pension disability allowance. Financial social assistance targets the most vulnerable groups in society. After Slovenian independence, there was a continuity in social assistance benefits, based on the Social Assistance and Services Act (SAS) of 1992. Means-tested financial social assistance to needy individuals did not change in the period 1993-19994 (Stropnik - Stanovnik 2002). The levels were low and insufficient to cover basic needs and therefore 'social assistance beneficiaries were not really pulled out of absolute poverty' (Stropnik - Stanovnik 2002: 94). The subsequent period was again marked by relatively gradual changes and in 2002, the SAS Act was amended, so that it introduced a minimum income and equivalence scale. There was also increasing emphasis on the activation of the recipients of social benefits (MDDSZ 2007: 6), in line with social investment approaches.

One major welfare policy change was the adoption of new social legislation that came into force in 2012, where the minimum income level was increased. The increased amount is however still insufficient to provide significant improvement in the recipient's living standards. Additionally, the strict order of claiming the various benefits (e.g. child benefits and others) and stricter means testing has had a negative impact on the financial situation of single-parent families, those with large loans, families with school-age children, large families, the elderly and couples without children (Dremelj et al. 2013). This was later addressed by certain additional smaller changes made to the legislation. Due to the conditions attached to the recipients of social assistance, single people represent the largest share (three quarters of the total), and the number of recipients of social assistance has steadily increased over recent years, from in 44,041 in December 2012, to 52,140 in December 2016 (Trbanc et al. 2017).

One further important shift in this policy area was the introduction of the activation principle, which was included in the Social Assistance Benefits Act (2010), and therefore the introduction of a social investment approach. The recipients of financial social assistance are thus able to increase the amount of their support if they are deemed active, that is if they are employed, participating in active labour market policy (ALMP) measures, participation in psychosocial rehabilitation programmes or performing voluntary work. The share of those receiving this increase in support was very low to begin with, being only $2.7 \%$

4 The 1992 SAS Act distinguished between individuals who were permanently unable to work (i.e. who are aged over 60 or not capable of working) and persons who were temporarily unable to secure sufficient minimum income. For the former group, the income was set at $60 \%$ of the guaranteed minimum wage, while for the latter, the support was set as the difference between their own income and the level of the minimum wage (Stropnik and Stanovnik, 2002:93). The financial assistance was limited to six months, with the possibility of an extension (MDDSZ, 2000). 
of all recipients in 2013. However, the share of recipients receiving this increase rose to $10.4 \%$ in 2016 (Trbanc et al. 2017).

In Montenegro, the area of social assistance and support is based on The Law of Social and Child Protection in Montenegro. This law provides material benefits and social services for different categories of children, the elderly, those in poverty, people with disabilities, and so on. There are different forms of financial benefits, targeting those in need, such as: financial support, personal disability allowance, benefits for the parents and guardians of recipients of personal disability allowance, one-off material support, assistance with burial costs, assistance for education, support for housing expenses, and transportation assistance.

In approving material benefits relating to material support, personal disability allowance, care support and benefits and one-off material support, Centres for Social Work ought to register evidence demonstrating the need for assistance and provide analyses and conclusions that might later be used as evidence. Through this mechanism, Montenegro provides a wide range of financial benefits that can provide significant support to vulnerable people. Naturally, there remains the issue of the strain due to processing requests relating to such a vast number of different types of support. In that sense, it would be preferable to merge some of these forms of support. Thus, in relation to financial assistance, the systems in both countries seem to function in a similar way; however, activation principles are not especially widely employed in Montenegro, while they seem to be increasingly applied in Slovenia.

\section{Reflections and conclusions}

The described social policy developments are an important part of the democratisation and transition process and illustrates the range of experiences found in the ex-Yugoslav countries, - where there is a historical legacy of diverse social policies, differing economic challenges and divergent responses to them, ranging from a more gradualist approach in Slovenia toward more ad hoc measures in Montenegro. Slovenia's transition to a free-market economy has been gradual. Social protection and investment policies have frequently been retained and have even, in some cases, been further expanded, while some have been gradually cut. The global economic crisis of 2008, profoundly affected many Slovenians, whilst also leading to several structural reforms along with ad hoc and temporary measures aimed at stabilising the public finances. The combination of these structural changes and austerity measures led to more abrupt changes in the country's welfare programmes, which have been subject to retrenchment through the increasing prevalence of needs testing and tighter qualification criteria, as well as the abolition of certain universal rights (see Filipovič Hrast - Rakar 2019). 
By contrast, the path taken by Montenegro has been different. In Montenegro, the measures employed by policy creators at the end of the 1990s were short-term, and mainly aimed at "putting out fires"; therefore, they were more regularly formed as ad hoc measures and reforms of the system. The dynamics of social reform were carried out in the direction of supporting certain segments of the population that had been targeted by state policy due to their particular vulnerability. During the period from 2003 to 2012, several strategies were created, and new instruments implemented in the areas of the labour market, social and child protection, education, pensions and disability insurance and health care. Furthermore, in all these areas, policy makers identified categories of population that were particularly marginalized. The resources of the Montenegro state (be those financial, infrastructural, or institutional) in the period 2003-2012 did not provide realistic opportunities for more universal approaches to social policy. However, since 2013, Montenegro has promoted a system to monitor the population of actual users of social services (via the ISSS-Social Card), and more or less developed mechanisms for identifying populations that might potentially be at greater social risks. These categories include people who are more difficult to employ for certain reasons, the elderly, the Roma population, refugees and others.

However, some similarities can also be identified between the two countries, such as e.g. the increased emphasis on activation measures in the field of the labour market. Additionally, both countries face certain similar challenges, such as an increasing ageing population that puts additional pressure on their pension systems, as well as high poverty rates among older people and the unemployed. An important challenge facing social policy development in Slovenia is addressing the needs of those groups that seem not to have benefitted from the economic recovery, and who remain trapped in poverty and social exclusion. These include the increasing problem of long-term unemployment and high at-risk poverty rates among the unemployed as well as the elderly, especially for single households (Filipovič Hrast - Rakar 2019).

Montenegro faces specific challenges related to the legacy of the delayed transition and its poor economic situation, with key challenges present in three areas. The first is labour market policy. The programme of reform of both social policy and employment policy (implemented 2015-2020) has identified a number of specific problems affecting the socio-economic stagnation of Montenegro, notably low employment rates and the high inactivity of the labour force; regional differences in the labour market; the under-employment of the local labour force; insufficient promotion of entrepreneurship; high levels of undeclared work; and youth unemployment with a special emphasis on the highly educated. Furthermore, and this is an issue that goes beyond just the labour market, - we have the challenge of the sustainability of the pension system. In relation to employment, there is also a need to harmonize the education 
system with the needs of the labour market. Further challenges in education include disadvantaged access to education for marginalized groups; low participation rates for all citizens in lifelong learning; the need to continuously improve the quality of education at all levels; the lack of practical training in educational programmes; and low levels of interest in education which is in short supply at the level of vocational education. The third key challenge is in the field of social and child protection, where there is an insufficiently developed system of services at the local level, a low level of access for people with disabilities and insufficient inclusion of socially vulnerable groups in relation to the labour market.

These challenges, while diverse, also have notable commonalities, in their focus on the ageing population and the reform of the pension system, the labour market and the needs of the most deprived. Although in Slovenia, the emphasis is still on a more universal social policy approach than in Montenegro, there has been an increasing focus on vulnerable groups in both countries, which can be partly explained by both countries adopting a more neoliberal targeted social policy agenda. Moreover, an emphasis on labour market activation and inclusion is prevalent in both countries and partly follows a social investment approach that emphasizes the relevance of labour market inclusion, but it can also partly be seen as a consequence of a more neoliberal agenda, with an emphasis on labour market participation (see Hemerijck 2013; Taylor Gooby et al. 2017). However, the two systems and their developments are more different than they are similar, which can be traced back to the beginning of the transition in both countries, the divergent paths that the countries have followed in tackling their social issues as well as the various pressures that they have faced over the last three decades.

These developments also indicate a variation in the democratisation processes of both countries. According to the Democracy Index of 2019, Montenegro is ranked 84th in the world. In comparison to Slovenia (36th place, 7.50 points) it is significantly lower in relation to the intensity of the process of democratization, and even recorded a large drop from 2006 to 2019. As some of the democratisation indexes (e.g. Bertelsmann Stiftung Transformation Index, see Komar - Novak 2020) include socioeconomic development and welfare system development as important indicators of democratisation, we can conclude based on our comparative analysis, that Slovenia has a more developed welfare system, while Montenegro is still lagging behind, especially in relation to the more universal approach and the greater number of social investment oriented measures that exist in Slovenia (e.g. within family policy). However, Slovenia has experienced important effects from both the economic crisis and the gradual retrenchment of the system, which could perhaps also be linked to the rather more critical opinions of its people on the social and political system and their lower confidence in social security systems in comparison to the 
population of Montenegro (see Komar - Novak 2020). One important facet of democratisation is responsiveness to the needs of citizens and the implementation of policies that people support, and several of retrenchment measures were highly contested in Slovenia (e.g. pension reform). Thus, there is a clear and important common challenge for both countries: how to address the welfare needs of the people when economic and/or demographic trends complicate rather than assist that process.

\section{References}

Ardarenko, Mihal - Djurovic, Gordana (2004): Socijalna politika u Srbiji i Crnoj Gori, Socijalni rad i socijalna politika, Fakultet politićkih nauka, Beograd

Bešić, Miloš - Đukanović, Borislav (2000): Svjetovi vrijednosti. Preobražaj društvene svijesti u Crnoj Gori, Podgorica, CID, SOCEN.

Bohle, Dorothee - Greskovits, Béla (2007): Neoliberalism, Embedded Neoliberalism and Neocorporatism: Towards Transnational Capitalism in Central Eastern Europe. West European Politics 30 (3): 433-466.

Daly, Mary (2011): Welfare, Cambridge, Polity Press.

Dremelj, Polona - Smolej, Simona - Boškić, Ružica - Narat, Tamara - Rihter, Liljana - Kovač, Nadja - Kobal Tomc, Barbara (2013): Ocena učinkov izvajanja nove socialne zakonodaje: končno poročilo, Ljubljana, Social Protection Institute of the Republic of Slovenia.

Esping-Andersen, Gøsta (1990): The Three Worlds of Welfare Capitalism, Princeton, New Jersey, Princeton University Press.

Eurostat (2018): Social Protection Expenditure Database: available at: http://ec.europa.eu/ eurostat/data/database (27 October 2018).

Eurostat (2019): LMP expenditure: available at https://webgate.ec.europa.eu/empl/redisstat/ databrowser/view/LMP_IND_EXP/default/table?category=Imp_indic (29 January 2020).

Ferge, Zsuzsa (2001): Welfare and 'Ill-Fare' Systems in Central-Eastern Europe, in Sykes, Robert Palier, Bruno - Prior, Pauline M., eds., Globalization and European Welfare States: Challenges and Change, 127-152, Hampshire, New York, Palgrave.

Filipovič Hrast, Maša, - Rakar, Tatjana (2019): The Development of the Slovenian welfare system, in Schubert, Klaus - Blum, Sonja - Kuhlmann, Johanna, eds., Routledge Handbook of European Welfare Systems, 483-501, London, New York, Routledge.

Filipovič Hrast, Maša - Rakar, Tatjana (2017): The Future of the Slovenian Welfare State and Challenges to Solidarity, in Taylor Gooby, Peter - Leruth, Benjamin - Chung, Heejung, eds., After Austerity: Welfare State Transformation in Europe after the Great Recession, 115-135, Oxford, Oxford University Press.

Hemerijck, Anton (2013): Changing welfare states, Oxford, Oxford University Press. 
Hlebec, Valentina - Rakar, Tatjana (2017): Aging policies in Slovenia: Before and After "Austerity", in Tomczyk, Łukasz - Klimczuk, Andrzej, eds., Selected Contemporary Challenges of Ageing Policy, 27-52, Kraków, Uniwersytet Pedagogiczny w Krakowie.

Ignjatović, Miroljub (2002): Družbene posledice povečanja prožnosti trga delovne sile, Ljubljana, Fakulteta za družbene vede.

Ignjatović, Miroljub - Kopač, Anja - Svetlik, Ivan - Trbanc, Martina (2002): Slovenia's navigation though a turbulent transition, in Goul Andersen, Jørgen - Clasen, Jochen - Van Oorschot, Wilm - Halvorsen, Knut, eds., Europe's New State of Welfare, 195-216, Bristol, The Policy Press.

Ignjatović, Miroljub - Filipovič Hrast, Maša (2018): Slovenian labour market policies under austerity: Narrowing the gap between the well- and the less well-protected in the labour market?, in Theodoropoulou, Sotiria eds., Labour market policies in the era of pervasive austerity: A European perspective, 309-336, Bristol, Chicago Policy Press.

Janković, Uglješa (2012): Socio-demografski prediktori socio-ekonomskog statusa građana, Skoplje, Zbornik radova, Kiril i Metodija.

Janković, Uglješa (2013): Socijalna inkluzija siromašnih u Crnoj Gori, Beograd, Čigoja štampa.

Kanjuo Mrčela, Aleksandra - Ignjatović, Miroljub (2015): Od prožnosti do prekarnosti dela: stopnjevanje negativnih sprememb na začetku 21. stoletja, Teorija in praksa 52 (3): 350-381, 563-564.

Katnić, Milorad (2017): (Ne)zaposlenost mladih u Crnoj Gori. Politike povećanja zaposlenosti mladih, UNDP Montenegro, Podgorica.

Kolarič, Zinka - Kopač, Anja - Rakar, Tatjana (2009): The Slovene welfare system: Gradual reform instead of shock treatment, in Schubert, Klaus - Hegelich, Simon - Bazant, Ursula, eds., The handbook of European welfare systems, 444-461, London, New York, Routledge.

Komar, Olivera - Novak, Meta (2020): Introduction: (De)democratisation in Slovenia and Montenegro: Comparing the Quality of Democracy. Politics in Central Europe Journal 16 (3). Doi: 10.2478/pce-2020-0026.

Kopač, Anja (2005): Od brezpogojne k pogojevani državi blaginje - spremembe znotraj koncepta državljanstva. Družboslovne razprave 21 (49/50): 51-64.

Lakićević, Dušan, (1997): Ekonomska, socijalna i politička kataklizma jugoslovenskog društva, Socijalna politika i socijalni rad 33 (3): 7-28.

Lazić, Mladen (2000): Elite u post-socijalističkoj transformaciji srpskog društva, Beograd, Filip Višnjić.

Lazić, Mladen (2011): Dometi tranzicije od socijalizma ka kapitalizmu, Zbornik radova. Friedrich Ebert Stiftung, Beograd.

Madžar, Ljubomir (2000): Politički uzroci siromaštva, Izdavačka knjižarnica Zorana Stojadinovića, Sremski Karlovci, Novi Sad.

Milosavljević, Milosav (2004): Devijacije i društvo, Beograd, Draganić.

The Law on Social and Child Protection (2013): Official Gazette of Montenegro, 27/2013, 1/2015, 42/2015, 47/2015, 56/2016, 66/2016, 1/2017, 31/2017 - decision of the CC, 42/2017, 50/2017.

Social Assistance Benefits Act (2010): Official Gazette of Slovenia, 61/10, 40/11, 14/13, 99/13, 90 $/ 15,88 / 16,31 / 18,73 / 18$. 
Social Assistance and Services Act (1992): Official Gazette of Slovenia, 3/07 -, 23/07 popr., 41/07 - popr., 61/10 - ZSVarPre, 62/10 - ZUPJS, 57/12, 39/16, 52/16 - ZPPreb-1, 15/17 DZ, 29/17, 54/17, 21/18 - ZNOrg, 31/18 - ZOA-A, 28/19.

MDDSZ (2007): Dopolnilo Nacionalnega poročila o strategijah socialne zaščite in socialnega vključevanja za obdobje 2006-2008", Ljubljana, September 2007: available at: www.mddsz. gov.si/fi leadmin/mddsz.gov.si/pageuploads/dokumenti__pdf/nap_soc_zascita_dop.pdf (18 June 2018).

Ministarstvo rada i socijalnog staranja (2003): Strategija redukcije siromaštva u Crnoj Gori, Podgorica, Službeni glasnik Crne Glasnik.

Ministarstvo rada i socijalnog staranja (2013): Zakon o socijalnoj i dječjoj zaštiti Crne Gore, Podgorica, Službeni glasnik Crne Gore.

Ministarstvo rada i socijalnog staranje Crne Gore - Zavod za socijalnu i dječju zaštitu, UNICEF (2018): Analiza potreba centara za socijalni rad Crne Gore, Podgorica, UNICEF Montenegro.

Ministarstvo zdravlja, rada i socijalnog staranje Crne Gore (2007): Strategija za suzbijanje siromaštva i socijalne isključenosti, Podgorica, Službeni glasnik Crne Gore.

Monstat (2016-2019): Statistical office of Montenegro: available at https://www.monstat.org/ eng/ (4 May 2020).

IDEAS, (2019): Analiza potreba centara za socijalni rad u Crnoj Gori, UNICEF Montenegro, Ministarstvo rada i socijalnog staranja Crne Gore, Zavod za socijalnu i dječju zaštitu Crne Gore, Podgorica.

Rakar, Tatjana. (2015): Country report for Slovenia, Eurofound project »Families in the economic crisis: mapping policy responses in five European member states, Eurofound Work Programme 2013-2016, IRSSV, Ljubljana

Stambolieva, Marija (2016): Welfare state transformation in the Yugoslav successor states, London, Routledge.

Stanovnik, Tine (2002): The political economy of pension reform in Slovenia, in Fultz, Elaine, ed., Pension Reform in central and Eastern Europe, ILO CEET, International Labour Organisation, Budapest.

Stropnik, Nada (2014): Investing in Children: Breaking the cycle of disadvantage, a study of national policies, Slovenia, Ljubljana, Institute for economic research.

Stropnik, Nada (2015): ESPN Thematic Report on minimum income schemes Slovenia 2015: available at http://ec.europa.eu/social/BlobServlet?docld=15175 \& langld=en (30 September 2018).

Stropnik, Nada - Stanovnik, Tine (2002): Combating poverty and social exclusion, Volume 2A case study of Slovenia, International Labour Office, Budapest.

Taylor Gooby, Peter - Leruth, Benjamin - Chung, Heejung (2017): After Austerity: Welfare State Transformation in Europe after the Great Recession, Oxford, Oxford University Press.

Trbanc, Martina - Smolej Jež, Simona - Dremelj, Polona - Narat, Tamara - Kobal Tomc, Barbara (2017): Socialni položaj v Sloveniji 2015-2016, končno poročilo, Ljubljana, Inštitut Republike Slovenije za socialno varstvo. 
Verbič, Miroslav (2009): A Note on Varying the Parameters of the Slovenian Pension System: An Analysis of Supplementary Pension Insurance. Post-Communist Economies 21 (3): 373-382. Zavod za statistiku Crne Gore (2003): Popis u Crnoj Gori, Podgorica.

Zavod za statistiku Crne Gore (2011): Popis u Crnoj Gori, Podgorica.

Zavod za zaposljavanje Crne Gore (2018): Zaposlenost i nezaposlenost u Crnoj Gori, Podgorica. World Bank (2019). World Bank data. Available at https://data.worldbank.org/ (accessed 30. 10. 2019.

Maša Filipovič Hrast is a Senior Researcher and Associate Professor at the Faculty of Social Sciences of the University of Ljubljana. Her research topics are social policy, housing policy, social inclusion and care and she has been involved in several international and national research projects linked to social policy and the welfare state.Email:masa.filipovic@fdv.uni-lj.si.

Uglješa Janković is a Researcher and Assistant Professor at the Faculty of Political Science of the University of Montenegro. He is also a Lecturer at the Faculty of Social Work in Belgrade, Serbia. His fields of research involve studies in social policy, sociology, social protection, migration policy and public policy.Email: jankovicugljesa@ yahoo.com.

Tatjana Rakar is a Researcher and Assistant Professor at the Faculty of Social Sciences of the University of Ljubljana. Her fields of research involve studies in social policy, family policy and third sector developments, where she has been involved in several national and international research project.Email: tatjana.rakar@fdv.uni-lj.si. 